SIR,-While not wishing to criticize an excellent piece of work on the rhynchonellids of the Boueti Bed in your January number by Messrs. Aitken and McKerrow (with whom I have unfortunately lost contact since accompanying them on the field party on which the material in question was collected), I do feel that some additional information would greatly increase the value of the paper.

The term community implies a strictly contemporaneous existence in a very restricted locality and the palaeontologist who uses it is making a very exacting claim for his work. The material from a random collection from the shore at Langdon Herring does not at first sight appear to constitute a community, though it might approximate to one if $R$. bouet $i$ is substantially absent from the other strata associated with the Boueti Bed and if the front on which the material was collected was sufficiently restricted.

It would be very interesting if this " community " can be established to know, too, something about the lithology and associated fauna, since a community is in complete ecological equilibrium; that is to say equilibrium with its physical and biological environment. Is there any chance of mixing of forms from a different environment by sampling or by transportation at the time of deposition? Do, for example, separate, worn, or broken valves occur and do the Polyzoa throw any light upon the environment? It is again emphasized that in the opinion of the writer the paper remains of great value for its method of treatment and this letter is merely a request that the authors " give us more". The results obtained would seem to be of much greater interest if they could be augmented by palaeoecological data as well.

F. W. Beales.

McMaster University, Canada. 12 th March, 1948.

\title{
CAUSES OF ICE AGE
}

SIR,-Geologists and others who concern themselves with past climates, and particularly with those of Pleistocene times, have reason to be indebted to Dr. Fuchs and Mr. Paterson for their illuminating contribution to the vexed problem of the inception and development of an ice age, and for the sound contention that the Glacial Period has no single cause, but resulted from a combination of circumstances which could hardly have arisen except during a period of orogeny (Fuchs and Paterson, 1947).

That no one factor is alone responsible for the advent of the great glaciations that have punctuated the geological record has long been recognized; and Brooks, while stressing the importance of con- 
tinentality, writes: "The greatest extremes of climate are not to be attributed to the normal development of one factor, but to the co-operation of a number of different factors acting in the same direction " (Brooks, C.E.P., 1926).

Thirteen years ago I called attention to the necessity of a multiple hypothesis in this regard in a postscript to my presidential address to the Uganda Society (Wayland, 1935). After some remarks concerning Milankovitch's work on the solar radiation curve, which had just reached me, I wrote :-

Granting the figures . . . and the correctness of the interpretation of the glacial succession in Europe, the curve deduced from the former is found to fit the latter astonishingly well, and thus, on the face of things, it would seem that here we have a complete explanation of glacial and interglacial periods; but it cannot be claimed that any explanation of the Great Ice Age is thereby given.

Milankovitch's hypothesis is on trial ; but if we assume for purposes of discussion that it is correct, it modifies Simpson's hypothesis in so far as variations of glacial climate are concerned, and thereby rids it of what is to my mind the unfortunate necessity of duplicating the curve within a time-span that seems hardly suited to the general hypothesis; and by bringing in Brooks's theory of . continentality we have an explanation not only of glacials and interglacials but of ice ages upon which these fluctuations are superimposed.

Granting tentatively that (as Simpson holds) the sun is a very long period variable star and that evaporation and precipitation will increase on earth with the amount of solar radiation received, it would seem that only those cycles of high radiation which synchronize with periods of high land elevation can produce glaciation, and that it is only during periods of glaciation (ice ages) that Milankovitch's three astronomical factors can function as controls in the variation of glacial climates.

In - brief, a case can be made to indicate that ice ages depend for their existence on the coincidence of high land and high solar radiation, and if the sun is a variable star (even though it be one of very long period) such coincidence is almost bound to occur. Given an Ice Age, astronomical factors (such as those employed by Milankovitch in his hypothesis) by their influence on the amounts of solar radiation received by the earth, control variations of glacial climate.

Three things are thus hypothetically explained : (1) the cause of an ice age ; (2) the synchronism of geological revolutions and ice ages; and (3) the reasons for glacial and interglacial periods as integral parts of an ice age. The validity of this compound hypothesis remains to be proved or disproved.

To this complex Fuchs and Paterson have added some effects of volcanism, clearly an important matter, which although considered before, particularly by Humphries (4), seems to have dropped out of our calculations of late. They also incorporate, rightly I believe, 
Paschinger's work on the depression of the snow line to and below the level of maximum snow deposition. These authors lay great stress on the climatic effects of volcanic dust in the atmosphere of Pleistocene times, and make out a good, but, as yet not unassailable, case in favour of phases of more or less world-wide volcanism sufficiently synchronous to have played a significant part in shaping the climatic episodes of the Great Ice Age. The authors' admission, however, that dust-laden atmosphere is by itself insufficient to promote an ice age seems to be supported by the intensity-distribution of the climatic changes and regimes. Presumably the nearer a volcanic centre the more marked the climatic effects should be, but this seems hardly substantiated by the facts. In the Bechuanaland Protectorate, for instance, where at intervals during nearly five years $I$ have been working on the problem of Pleistocene climates, the effects are very marked, although the nearest volcanoes (excepting the small Pretoria salt pan) which might have contributed dust to the atmosphere in former times are some 1,500 miles away. The climatic sequence of the Kalahari parallels that of East Africa on the one hand and that of the Vaal River basin as worked out by Sohnge and Visser (1937) on the other.

The fact that the Pleistocene pluvials of Eastern and Central Africa were ushered in by great earth movements, and accompanying volcanicity, seemed too marked to be entirely coincidental, and it has rendered the disentanglement of events and the apportioning of them to their proper spheres a difficult task in Uganda, from which country conveniently enclosed basins like those of the Kenya Rift valley are absent (except for relatively small crater lakes), and the maximum height of Lake Victoria has depended upon the altitude of its outlet rather that upon the rainfall.

With low lake levels and their oscillations the matter has usually been different, but one must turn to the river valleys for climatic evidence, for clearly high precipitation might easily synchronize with a tectonically controlled low-level Lake Victoria, and if the present outlet at the Ripon Falls were raised, say, by 50 feet, the lake would presumably rise to this level without increase in rainfall, and the fact that, in spite of theoretically reduced evaporation consequent upon a dust-laden atmosphere, rivers have run strongly during the pluvials seems to favour Simpson's hypothesis and to suggest that the dust mantle was shorn of much of its power to influence climate because of the more dynamic effects of solar radiation. In these circumistances the dust mantle might locally reduce the temperature and assist in precipitation of moisture gathered elsewhere and brought in by favourable winds. This, however, is speculation, and at present we are short of facts. 
That a volcanic dust mantle hung over much of East Africa (and probably over other parts of the earth when and where volcanicity occurred) in Pleistocene time there can be little doubt; much of this may have been precipitated by rain, and the high content of almost unweathered volcanic material, particularly tiny sanidine crystals, in the pluvial lake deposits of the Eastern Rift valley, may perhaps be thus explained. It is to be noticed, too, that these fine-grained sediments extend right to the rock escarpments in many places, a fact which argues against an arid or semi-arid climate during the days of this subaqueous deposition.

To summarize : one may say that the time is passed when lack of information permitted one to ascribe a single dominating cause to the ice age. To-day we must speak of causes in this regard. We are, I think, advancing toward a clearer understanding of these, and the resuscitation and restatement of the volcanic contribution is not a retrograde step, but one which, when fully assessed, will further that advance.

\section{E. J. WAYLAND.}

GABERONES,

Bechuanaland Protectorate.

20 th March, 1948.

Brooks, C. E. P., 1926. Climate Through the Ages.

Fuchs, V. E., and PATERson, T. T., 1947. The Relation of Volcanicity and Orogeny to Climatic Change: Geol. Mag., lxxxiv, 321.

Humprereys, W. J., 1920. Physics of the Air, Philadelphia; and later works.

Paschinger, V., 1923. Die Eiszeit ein meterologische Zyklus. Zs. $f$. Gletscherk, 13 (quoted from Climate Through the Ages).

SOHNGE, P. G., and VISSER, D. J. L., 1937. The Geology and Archaeology of the Vaal River Basin. Geol. Surv. Union. S. Af. Mem., 35.

Wayland, E. J., 1935. Past Climates and some Future Possibilities in Üganda. Uganda Journal, iii, No. 2, October.

\section{LONGMYNDIAN STRATIGRAPHY}

SiR,-Mr. Challinor's demonstration, in his article in the Geological Magazine for March-April, 1948 (p. 107), that, on the evidence of graded bedding, the eastward dipping Eastern Longmyndian rocks in a quarry on Haughmond Hill are right way up is of considerable interest.

His conclusion that " in Haughmond Hill the Eastern Longmyndian both actually and also stratigraphically overlies the Western Longmyndian " by no means necessarily follows, however, and, indeed, would increase rather than otherwise the difficulties of interpretation of Longmyndian stratigraphy. 